\title{
Serial plasmapheresis in a haemophiliac with antibodies to FVIII
}

\author{
R. COBCROFT, G. TAMAGNINI, AND KATHARINE M. DORMANDY
}

From the Haemophilia Centre, Department of Haematology, Royal Free Hospital, London NW32QG

SUMMARY Serial plasmaphereses were performed on a 23-year-old haemophiliac, withi antibodies to factor VIII (FVIII), in order to reduce the antibody level before multiple dental extractions. Eight phereses were carried out in which approximately 1.5 litres plasma was exchanged with isotonic saline. By the ninth exchange, which was carried out immediately before the extraction, the antibody level had fallen from $4 \mathrm{u} / \mathrm{ml}$ to $0.8 \mathrm{u} / \mathrm{ml}$. On this occasion fresh frozen plasma and FVIII concentrate were infused immediately after the pheresis. A normal post-infusion level of FVIII was achieved with a normal half disappearance time of the infused FVIII.

Patients with haemophilia A, who have developed antibodies to factor VIII (FVIII), often present a difficult clinical problem because of the very large quantities of FVIII concentrate which may be needed to neutralise the antibody before the patient's own FVIII level can be raised. The technique of plasma exchange transfusion, as a means of reducing the antibody immediately before FVIII replacement, has been very much simplified by the use of centrifugal cell separators (Edson et al., 1973). The effect of a single exchange transfusion, however, is limited by the diffusion back of the IgG FVIII antibody from the extravascular pool. The report of Pole et al. (1974), that serial plasmaphereses could be used to lower the total anti-D antibody level in pregnant women with severe $R h$ sensitisation, prompted us to try this method in a patient with severe haemophilia complicated with antibodies who required elective tooth extractions.

\section{Case report}

JL, aged 23 , was a severely affected haemophiliac who had been intensively treated with blood products from the age of 15 months to 14 years when he developed FVIII antibodies; from this time on, blood products were given only for the more serious bleeds. While the clinical response to these infusions varied from good to ineffective, the in-vivo FVIII recovery was always poor. (Four weeks before the plasmapheresis regime was started, for example, at a time when the antibody level was $1.1 \mathrm{u} / \mathrm{ml}$, the

Received for publication 9 February 1977 post-infusion level of FVIII after the administration of 4500 u FVIII was only $6 \%$, representing a recovery of only $3 \%$.) Attempts to alter the antibody production with a variety of immunosuppressive drugs, including cyclophosphamide, azathioprine, and corticosteroids, failed to provide a regime which regularly suppressed the post-treatment antibody rise (Dormandy, 1975). In April 1975, when the patient's antibody level was $4.5 \mathrm{u} / \mathrm{ml}$, a previously troublesome abscess in an impacted wisdom tooth recurred. As he had several other carious teeth, it was decided to remove all these at the one operation. Within the past three years, this patient's antibody level had never been less than $1 \mathrm{u} / \mathrm{ml}$, and as he had been treated with FVIII four weeks earlier, the chances of a spontaneous drop to $1 \mathrm{u} / \mathrm{ml}$ or less within the next four months seemed exceedingly remote. In an attempt to expedite the antibody fall nine plasmaphereses were performed. At each of the first eight, an average of 1.51 plasma was removed and replaced with normal saline. On two runs, $2 \times$ $10^{9}$ white cells, $85 \%$ lymphocytes, were also taken. The ninth pheresis was on the morning of the operation. On this occasion approximately $500 \mathrm{ml}$ (two packs) of fresh frozen plasma (FFP) were returned to the patient. This was immediately followed by 12500 units FVIII concentrate (Lister Institute), which was infused over one hour. A further 5000 units concentrate was given 24 hours later.

At operation eight teeth, including four wisdom teeth, two of which were impacted, were removed. Splints were applied, and intravenous EACA, $5 \mathrm{~g}$, was given six-hourly for three days followed by oral 
tranexamic acid, $1.5 \mathrm{~g}$ four times a day. Septrin (two tablets twice daily) was given for seven days postoperatively.

\section{SIDE EFFECTS OF PLASMAPHERESIS AND}

GENERAL OUTCOME

Apart from a vasovagal attack, which occurred during one of the plasmaphereses, no significant complications arose and there was no damage to veins. Healing of the tooth sockets was uneventful.

\section{Methods}

Plasmapheresis was carried out with a Haemonetics Model 30 Cell Separator, using a $275 \mathrm{ml}$ bowl and ACD, USP formula A, as an anticoagulant.

Factor VIII assays were carried out by the method of Biggs et al. (1955).
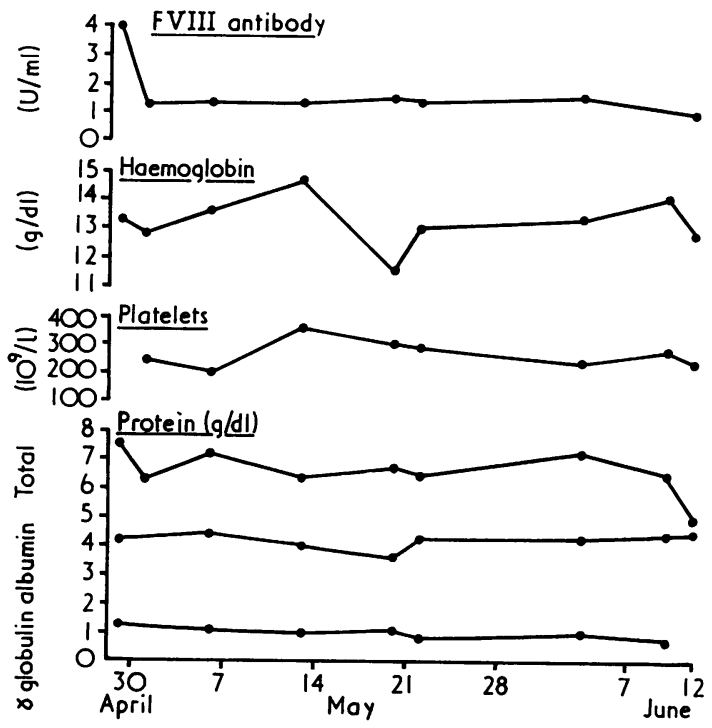

Fig. 1 Preplasmapheresis levels of various parameters during serial plasmapheresis.
Factor VIII antibody levels were measured by the method of Biggs and Bidwell (1959) using highpotency human cryoprecipitate for the added FVIII. One unit of antibody is the amount which neutralises $75 \%$ of the added FVIII in one hour. Total proteins and albumin were estimated by automatic analysis; globulins were measured by electrophoretic scan.

\section{Results}

The results of the various tests are shown in Fig. 1 and in the Table. The factor VIII antibody level fell from $4 \mathrm{u} / \mathrm{ml}$ at the beginning of the first plasmapheresis to $0.8 \mathrm{u} / \mathrm{ml}$ at the beginning of the last.

Albumin levels were well maintained despite replacement with normal saline alone. The reduced levels obtained immediately after plasmapheresis had been corrected by the time the next pre-plasmapheresis sample was taken. The total $\gamma$ globulin level dropped significantly.

The FVIII and antibody response to the infusions of FVIII concentrate at the time of dental extraction are shown in Figure 2.

\section{Discussion}

At the time of the first plasmapheresis this patient's FVIII antibody level was following a typical wave pattern in response to an infusion of FVIII which had been given four weeks previously. Since two consecutive antibody levels had been recorded as 4.5 and 4 units $/ \mathrm{ml}$ respectively, it can be assumed that the peak antibody level had already been passed or at least reached. Plasmapheresis appeared to accelerate the natural antibody fall because the level, at the end of the eight phereses, was the lowest recorded for three years. Contraction of the antibody pool is suggested by the normal half disappearance time of both doses of infused FVIII (Fig. 2).

It seems likely that serial plasmapheresis will be most valuable in those patients in whom the peak antibody level has been passed, even though such

Table Effect of serial plasmapheresis on levels of FVIII antibody $(u / m l)$ and plasma proteins $(\mathrm{g} / \mathrm{dl})$

\begin{tabular}{|c|c|c|c|c|c|c|c|}
\hline \multirow[t]{2}{*}{ Date } & \multirow{2}{*}{$\begin{array}{l}\text { FVIII antibody } \\
\text { level } \\
\text { Pre }\end{array}$} & \multicolumn{2}{|c|}{ Total protein } & \multicolumn{2}{|c|}{ Albumin } & \multicolumn{2}{|c|}{ Gamma globulin } \\
\hline & & Pre & Post & Pre & Post & Pre & Post \\
\hline $\begin{array}{l}\text { April } 29 \\
\text { May } 1 \\
\text { May } 6 \\
\text { May } 13 \\
\text { May } 20 \\
\text { May } 22 \\
\text { June 3 } \\
\text { June } 10\end{array}$ & $\begin{array}{l}4 \cdot 0 \\
1 \cdot 2 \\
1 \cdot 3 \\
1 \cdot 2 \\
1 \cdot 4 \\
1 \cdot 2 \\
1 \cdot 4 \\
0 \cdot 8\end{array}$ & $\begin{array}{l}7 \cdot 5 \\
6 \cdot 2 \\
7 \cdot 1 \\
6 \cdot 3 \\
6 \cdot 6 \\
6 \cdot 5 \\
7 \cdot 0 \\
6 \cdot 4\end{array}$ & $\begin{array}{l}6 \cdot 7 \\
5 \cdot 1 \\
5 \cdot 6 \\
5 \cdot 8 \\
5 \cdot 8 \\
4 \cdot 7 \\
5 \cdot 2 \\
4 \cdot 5\end{array}$ & $\begin{array}{l}4 \cdot 2 \\
4 \cdot 3 \\
3 \cdot 9 \\
3 \cdot 6 \\
4 \cdot 3 \\
4 \cdot 1 \\
4 \cdot 2\end{array}$ & $\begin{array}{l}3 \cdot 9 \\
3 \cdot 0 \\
3 \cdot 5 \\
3 \cdot 6 \\
3 \cdot 1 \\
2 \cdot 7 \\
2 \cdot 9 \\
3 \cdot 3\end{array}$ & $\begin{array}{l}1.3 \\
0.9 \\
0.8 \\
1.0 \\
0.7 \\
0.8 \\
0.6\end{array}$ & $\begin{array}{l}0.9 \\
0.8 \\
0.7 \\
0.7 \\
0.8 \\
0.4 \\
0.5 \\
0.5\end{array}$ \\
\hline
\end{tabular}




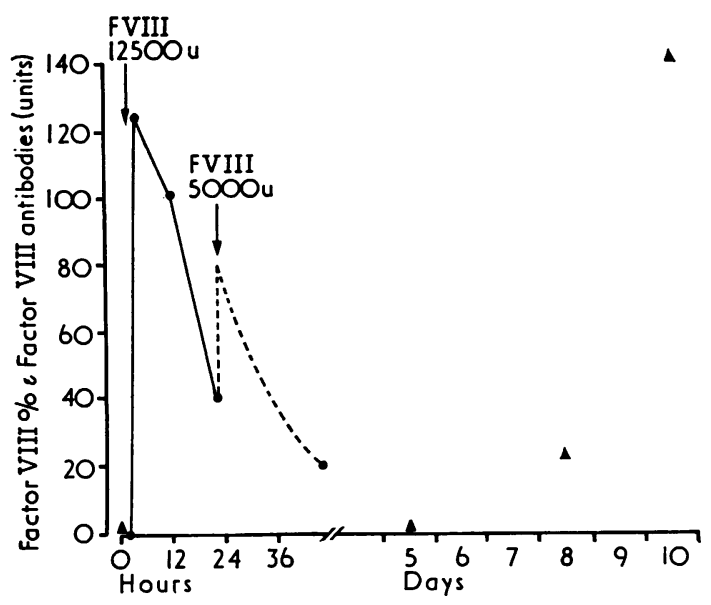

Fig. 2 Response to factor VIII infusion after serial plasmapheresis. . . . predicted response to second factor VIII infusion; $\Delta$ antibody levels.

patients may still be synthesising some antibody. In patients in whom the antibody is rising, the progressive fall brought about by plasmapheresis is much more likely to be annulled by newly synthesised antibody. If planned surgery is contemplated in such a patient, serial plasmapheresis should be delayed until the peak antibody level has been passed. In an emergency, intensive plasmapheresis before FVIII replacement may be appropriate but, where surgery is concerned, this approach is strictly limited. This is illustrated in a patient described by Edson et al. (1973) in whom the first intensive plasmapheresis was successful, while a second some days later was much less effective because of the anamnestic antibody rise.

One important feature of this study was the inadvertent saving of blood products generally given to replace plasma protein loss through plasmapheresis. In order to prevent stimulating an antibody rise, the 1.5 litres of plasma removed during the first eight plasmaphereses was replaced by saline and not by fresh frozen plasma or plasma derived products. This was accomplished without harm to the patient and without serious drop in plasma protein levels.

We thank Miss Janis Warren for antibody assays and coagulation studies and Professor D. N. Baron for permission to publish the biochemical data. The Royal Free Hospital Haemophilia Centre is recognised as an international training centre of the World Federation of Haemophilia.

\section{References}

Biggs, R. and Bidwell, E. (1959). A method for the study of antihaemophilic globulin inhibitors with reference to six cases. British Journal of Haematology, 5, 379-395.

Biggs, R., Eveling, J., and Richards, G. (1955). The assay of antihaemophilic-globulin activity. British Journal of Haematology, 1, 20-34.

Dormandy, K. M. (1975). Immunosuppression in the treatment of haemophiliacs with antibodies to factor VIII. In Proceedings of the IXth Congress of the World Federation of Hemophilia, Istanbul, 1974. (Excerpta Medica International Congress Series, no. 356), edited by O. N. Ulutin and I. R. Peake, p. 225. Excerpta Medica, Amsterdam.

Edson, J. R., McArthur, J. R., Branda, R. F., McCullough, J. J., and Chou, S. N. (1973). Successful management of a subdural hematoma in a hemophiliac with an anti-factor VIII antibody. Blood, 41, 113-122.

Pole, J. R. G., Barr, W., and Willoughby, M. L. N. (1974). Continuous-flow exchange-plasmapheresis in severe Rhesus isoimmunisation (Letter). Lancet, 1, 1051. 